\title{
Quality characteristics of extruded rice snacks based on the rice cultivar and corn flour ratio
}

\author{
Jung-Min Kim ${ }^{1}$, Jun-Hyeon $\mathrm{Cho}^{2}$, Woo-Duck Seo ${ }^{3}$, Kwang-Sup Youn ${ }^{1,4 *}$ \\ ${ }^{1}$ Department of Food Science and Technology, Daegu Catholic University, Gyeongsan 38430, Korea \\ ${ }^{2}$ Department of Southern Area Crop Science, NICS, RDA, Miryang 50424, Korea \\ ${ }^{3}$ Crop Foundation Division, NICS, Wanju 55365, Korea \\ ${ }^{4}$ Institute of Food Science and Technology, Daegu Catholic University, Gyeongsan 38430, Korea
}

\section{쌀 품종 및 옥수수 배합비율에 따른 팽화스낵의 품질 특성

\author{
김정민 ${ }^{1} \cdot$ 조준현 ${ }^{2} \cdot$ 서우덕 ${ }^{3} \cdot$ 윤광섭 $^{1,4 *}$ \\ ${ }^{1}$ 대구가톨릭대학교 식품공학과, ${ }^{2}$ 농촌진흥청 국립식량과학원 남부작물부, \\ ${ }^{3}$ 농촌진흥청 국립식량과학원 작물기초기반과, ${ }^{4}$ 대구가톨릭대학교 식품과학연구소
}

\begin{abstract}
In order to increase the usability of rice, this study was investigated the quality characteristics of extruded rice snacks based on the rice cultivar ('Aromi', 'Hanahreum', 'Jasmin 85' and 'Bukkyeong 2012') and ratio of com flour $(0,30,50,70$ and $100 \% \mathrm{w} / \mathrm{w})$ to rice flour. The moisture content and bulk density decreased as the amylose content decreased, whereas the porosity and expansion ratio tended to decrease with increasing amylose content. The strength and hardness increased significantly with the amylose content. The water solubility index and water absorption index decreased and increased, respectively, as the amylose content increased. The moisture content and the $L$ value increased significantly as the proportion of rice flour was increased, whereas the $b$ value decreased significantly. The bulk density increased with increasing rice flour content. The porosity, expansion ratio and specific length tended to increase as the amount of rice flour was increased. The strength and hardness were the lowest in extruded snacks made with $\mathbf{7 0 \%}$ of rice flour. The water solubility index and water absorption index increased significantly with increasing rice flour content. Therefore, the best quality characteristics were observed in extruded snacks made with the Aromi, and the optimal proportion of rice flour was $\mathbf{7 0} \%$.
\end{abstract}

Key words : rice flour, cultivar, extrusion, snack

서 론

쌀(Oryza sative L.)은 옥수수와 밀과 함께 세계 3대 곡물 로 가공식품으로 활용도가 높은 곡류 중의 하나이다. 우리나 라를 비롯한 아시아, 아프리카와 라틴 아메리카 지역의 주식 으로 이용되고 있으며, 특히 아시아 지역에서는 하루 섭취 열 량의 절반 이상을 쌀로부터 취하고 있다(Milner, 1999). 그러
나 식생활의 서구화 및 맞벌이 부부 증가 등과 같은 다양한 사회적 변화로 인하여 소비량은 매년 1-2 kg씩 점차 감소 추 세에 있어 2016년에는 $61.9 \mathrm{~kg}$ 까지 감소하였다(Statistics korea, 2018). 또한, 국내 쌀시장은 1 인당 쌀 소비량 감소와 FTA 등으로 인해 쌀의 공급량이 소비량을 앞지르는 초과공 급 현상이 발생하였으며(Choi, 2002), 이러한 쌀 소비 문제점 의 해결을 위해 쌀 식품 고급화를 위한 맞춤형 품종 개발 및

*Corresponding author. E-mail : ksyoun@cu.ac.kr, Phone :+82-53-850-3209, Fax : +82-53-850-3209

Received 11 May 2020; Revised 29 June 2020; Accepted 30 June 2020.

Copyright (c) The Korean Society of Food Preservation.

This is an Open Access article distributed under the terms of the Creative Commons Attribution Non-Commercial License (http://creativecommons.org/licenses/by-nc/4.0) which permits unrestricted non-commercial use, distribution, and reproduction in any medium, provided the original work is properly cited. 
가공 적성 연구 전략을 통해 국내 쌀의 경쟁력 향상 및 수요 확대에 노력하고 있으며, 쌀 소비 촉진을 위한 방안이 지속적 으로 필요한 실정이다(Han 등, 2012; Shin 등, 2008).

스낵(snack)이란 과자의 일부분으로 비교적 비중이 가볍고 가격이 싸고 부담 없이 먹을 수 있는 것을 말하며 곡류, 감자, 고구마, 콩, 전분, 견과류 및 육류 등을 원료로 사용하여 튀 김, 볶음, 압출성형, 팽화와 같은 공정을 거쳐 가볍게 즐기기 위한 식품을 말한다(Song과 Park, 1997). 우리나라 스낵은 처 음부터 소맥분계가 주류를 이루고, 그 다음 옥수수계통, 감자 계통, 쌀계통 등으로 원료를 다양화했지만, 아직도 소맥분계 가 다수를 차지하고 있다. 최근에는 건강지향형 스낵 및 노 인, 영유아를 대상으로 한 특수계층용 스낵에 대한 소비자의 수요가 증가하면서 다양한 물성이 요구되고 있으며(Le Reverend 등, 2014), 그 중 압출성형 스낵이 고유의 바삭거리 는 질감과 부드럽고 소화되기 쉬운 특성을 가져 스낵과자 시 장에서 높은 비중을 차지하고 있다.

압출성형공정은 고온, 고압, 고전단력 공정으로 전분의 호 화와 덱스트린화, 단백질의 변성 등 이화학적 변화가 일어나 며, $100^{\circ} \mathrm{C}$ 이상의 고온과 수분을 함유한 내부 용융물이 사출 구멍을 통하여 사출될 때 급격한 압력감소에 의해 용융물이 함유하고 있는 수분은 수증기로 상변화를 하는데 이 비체적의 증가로 인하여 점탄성을 가진 용융물은 팽화한다(Bouzaza 등, 1996; Harper, 1986). 특히 전분가공 분야에서 각광을 받고 있으며, 압출성형 제품은 스낵, ready-to-eat(RTE) cereals, 과 자류, 비스킷, 애완동물용 사료 등이 있다(Suknark 등, 1997). 그 중 곡류 스낵식품들은 너무 단단하거나 강함이 없이 아삭 아삭 소리나면서 밀도가 낮은 생산품으로 만드는 것이 목표 이다. 옥수수와 밀이 주로 압출 성형제품에 이용되는 전분재 료이고, 쌀은 비교적 많이 이용되지 않았지만 최근에 쌀은 알 레르기의 유발을 저하시킨 무글루텐(gluten free) 식품원료로 서 밀가루보다 영양적으로 우수하며 소화가 잘되는 특성이 있다고 보고되었다(Kang과 Ryu 2001). 또한, 팽화된 쌀가공 제품은 노화가 잘 되지 않아 상대적으로 오랫동안 품질 유지 가 용이하다는 특징을 가져 쌀가루와 옥수수가루의 비율을 달리하여 제조한 생선스낵(Sim 등, 2001), 저항전분 함유 고 아밀로스 품종의 현미 팽화 과자(Lee 등, 2017), 단호박 첨가 쌀 팽화스낵(Wu 등, 2018), 삼종실 압출성형물을 이용한 에 너지바 제조 $(\mathrm{Gu}$ 등, 2010), 갈색거저리 애벌레 첨가 쌀 팽화 스낵(Cho 등, 2017) 등 밀이나 옥수수를 쌀로 대체하거나 기 능성 물질을 첨가하여 영양과 기능성을 보완한 식품을 만들 려는 연구가 다양하게 진행되고 있으나, 압출성형물 제조에 적합한 쌀의 품종이나 대체비율에 따른 연구가 부족한 실정 이다.

따라서 본 연구에서는 쌀의 이용성 확대를 위한 제품개발
및 생산의 기초자료를 제시하고자 조직감과 팽화성이 우수한 팽화스낵 제조를 위하여 아밀로스 함량이 각각 다른 아로미 (Aromi), 한아름(Hanahreum), 자스민 85(Jasmin 85) 및 북경 2012-2(Bukkyeong 2012-2)를 사용하여 팽화스낵의 물리적 특성을 비교하였으며, 압출성형의 주된 재료로 이용되는 옥 수수가루와 쌀가루의 비율을 달리하여 제조한 팽화스낵의 품 질특성을 비교 분석하였다.

\section{재료 및 방법}

\section{재료}

본 연구에 사용한 쌀은 4종, 아로미(Aromi), 한아름 (Hanahreum), 자스민 85(Jasmin 85) 및 북경 2012-2 (Bukkyeong 2012-2)로 2017년 수확한 것으로, 국립식량과학 원으로부터 제공받아 사용하였다. 품종에 따른 아밀로오스 함량은 아로미 $21.39 \%$, 한아름 $22.27 \%$, 자스민 $8525.76 \%$ 및 북경 2012-2 34.12\%로 각각 나타났다. 옥수수가루는 팽 화스낵 제조용으로 판매되는 제품(옥수수 $100 \%$, 알파슈퍼 콘)을 (주)범아식품로부터 구입하여 사용하였다. 예비실험에 사용한 멥쌀가루는 2018년 수확한 단립종으로 아밀로오스 함량은 18.00-19.00\%이며, (주대두식품 햇쌀마루로부터 구입 하여 사용하였다. 방앗간에서 분쇄한 쌀가루와 옥수수가루 는 60 mesh 표준망체(Chung Gye Sang Cong Sa, Seoul, Korea)를 통과한 분말을 $-20^{\circ} \mathrm{C}$ 이하 암소에서 보관하면서 시 료로 사용하였다.

\section{쌀 팽화 스낵 제조}

압출성형기(extruder)를 이용한 스낵 성형을 위해 이축압 출성형기(FX60, Milling Industry Co., Seoul, Korea)의 원료 투입구에서 다이(die, $\phi 1 \mathrm{~mm}$ ) 전까지 3구역의 배럴온도를 각각 $50,70,110^{\circ} \mathrm{C}$ 로 조절하였고, 다이 온도를 $150^{\circ} \mathrm{C}$ 로 유지 하였다. 스크류 및 피딩 속도에 따라 예비실험을 진행하여 최 적 조건을 설정하였다. 즉, 스크류 회전속도 $900,1,000,1,100$, $1,200,1,300 \mathrm{rpm}$ 의 범위와, 원료투입 속도는 $300,350,400$, $450 \mathrm{rpm}$ 으로 조절하여 실험한 결과, 압출성형기기 최적공정 조건으로 스크류 회전속도 $1,200 \mathrm{rpm}$, 원료 투입량 $350 \mathrm{rpm}$ 으로 고정하여 쌀 품종에 따른 압출 팽화스낵을 제조하였다. 실험조건에 따른 압출 시료를 채취하여 $4 \mathrm{~cm}$ 크기로 절단 후 압출물의 성형특성을 분석하였다.

\section{쌀가루 및 옥수수 배합비에 따른 쌀 팽화 스낵 제조}

압출성형기 운용의 최적공정 조건에 따른 스크류 회전속 도 $1,200 \mathrm{rpm}$, 원료 투입량 $350 \mathrm{rpm}$ 으로 고정시키면서 옥수 수 가루 첨가량 $(0,30,50,70,100 \%)$ 에 따른 팽화스낵을 제 
조하였다. 실험조건에 따른 압출 시료를 채취하여 $4 \mathrm{~cm}$ 크기 로 절단 후 압출물의 성형특성을 분석하였다.

\section{수분함량 및 색도 측정}

수분함량은 적외선 수분측정기(HE53, Halogen Moisture Analyzer, Mettler-Toledo, Zurich, Switzerland)를 사용하여 측정하였고, 색도는 색차계(CR-300, Minolta Co., Osaka, Japan)로 측정하였으며, 밝기를 나타내는 L*(lightness), 적색 도를 나타내는 $a^{*}$ (redness), 황색도를 나타내는 $b^{*}$ (yellowness) 를 측정하였다.

\section{Bulk density, apparent density 및 porosity 측정}

Bulk density(체적밀도)는 스낵의 무게를 측정한 다음 종 자치환법(Pyler, 1979)으로 부피를 측정하여 무게를 부피로 나누어 나타냈다. Apparent density(실부피)는 시료 30개를 믹서로 2 분간 고속으로 마쇄한 후 $40 \mathrm{mesh}$ 로 하여 실린더로 실부피를 측정하였고, 무게를 실부피로 나누어 나타내었으 며, porosity(다공성)는 쌀 스낵의 bulk 부피와 실부피를 다음 과 같이 계산하였다(Yagci와 Gogus, 2008).

$$
\text { Porosity }=\frac{\text { Bulk volume }- \text { Apparent volume }}{\text { Bulk volume }}
$$

\section{Specific length 측정}

압출성형물의 specific length(비길이)는 일정한 길이로 절 단한 압출성형물의 길이와 무게의 비로 20 회 측정한 후, 아래 와 같은 계산식을 이용하여 평균값과 오차를 구하였다 (Bhatnagar와 Hanna, 1995).

$$
\text { Specific length }(\mathrm{mm} / \mathrm{g})=\frac{\text { Length of extrudate }}{\text { Weight of extrudate }} \times 100
$$

\section{직경팽화율 측정}

압출성형물의 길이는 캘리퍼스(CD-15C, Mitutoyo Co., Tokyo, Japan)를 이용하였고, 무게는 전자저울을 사용하였 다. 직경 팽화율은 캘리퍼스(CD-15C, Mitutoyo Co., Tokyo, Japan)로 10 회 측정하여 아래의 식을 이용하여 계산하였다. 사출구의 직경과 압출성형물 직경비의 평균값으로 산출하였 다(Yang 등, 2008).

$$
\text { Expansion ratio }=\frac{\mathrm{D}_{\text {extrudate }}}{\mathrm{D}_{\text {die }}}
$$

\section{조직감 측정}

강도 및 경도는 Rheometer(Compac-100, Sun Scientific Co., Japan)를 이용하여 test mode 20, tabled speed 120 $\mathrm{mm} / \mathrm{min}$, Probe No.1 $\$ 15 \mathrm{~mm}$ 조건에서 측정하였다.

\section{수분흡수지수(WAI) 및 수분용해지수(WSI) 측정}

수분흡수지수(water absorption index, WAI) 및 수분용해 지수(water solubility index, WSI) 측정은 Anderson과 Griffin (1969)의 방법을 변형하여 측정하였다. 시료 $1 \mathrm{~g}$ 에 $25 \mathrm{~mL}$ 증류수를 첨가하여 30 분간 상온에 방치한 후 $3,000 \mathrm{rpm}$ 에서 20 분간 원심분리하여 침전물은 수분흡수지수로 계산하였으 며, 상등액은 미리 무게를 구한 수기에 분리하여 $105^{\circ} \mathrm{C}$ 에서 4시간 동안 건조시킨 고형분을 수분용해지수로 사용하여 아 래와 같이 계산하였다.

$$
\text { WAI }=\frac{\text { Weight of sediment }}{\text { Weight of dry sample }}
$$

WSI $(\%)=$

$$
\frac{\text { Weight of dissolved solid in supernatant }}{\text { Weight of dry sample }} \times 100
$$

\section{시차주사열량분석(DSC)}

시차주사열량(differential scanning calorimetry, DSC) 분 석은 약 $1.5 \mathrm{mg}$ 의 시료를 hermetic pan에 정확히 칭량한 후 desiccator에서 하룻밤 동안 수분평형시킨 후 $\operatorname{DSC}(2010$, TA Instruments, New Castle, Delaware, USA)로 열분석하였다. 분석은 heating rate를 $10^{\circ} \mathrm{C} / \mathrm{min}$ 으로 하여 가열온도 $5-200^{\circ} \mathrm{C}$ 에서의 흡열 peak를 얻고, 이로부터 엔탈피 $(\mathrm{J} / \mathrm{g})$, 호화개시온 도(To), 호화피크온도(Tp), 호화종료온도(Tc)를 구하였다.

\section{통계처리}

모든 실험은 3회 반복으로 행하여 평균치와 표준편차로 나 타내었고, 유의성 검증은 SPSS 12(SPSS Inc., Chicago, IL, USA) software package program을 이용하여 Duncan's multiple range test를 행하였다.

\section{결과 및 고찰}

\section{품종에 따른 쌀 팽화스낵의 수분함량 및 색도}

쌀 품종별(아로미, 한아름, 자스민 85 및 북경 2012-2)에 따른 팽화스낵의 수분함량 및 색도는 Table 1과 같다. 팽화스 낵 제조를 위해 아로미, 한아름, 자스민 85 및 북경 2012-2 
Table 1. Moisture content and color of extruded rice snacks based on the rice cultivar

\begin{tabular}{|c|c|c|c|c|}
\hline \multirow{2}{*}{ Sample } & \multirow{2}{*}{$\begin{array}{c}\text { Moisture } \\
\text { content }(\%)\end{array}$} & \multicolumn{3}{|c|}{ Color value } \\
\hline & & Lightness $\left(\mathrm{L}^{*}\right)$ & Redness $\left(\mathrm{a}^{*}\right)$ & Yellowness $\left(b^{*}\right)$ \\
\hline ‘Aromi' & $6.65 \pm 0.14^{\mathrm{c} 1)}$ & $82.32 \pm 0.45^{\mathrm{a}}$ & $0.88 \pm 0.08^{\mathrm{b}}$ & $14.77 \pm 0.57^{\mathrm{a}}$ \\
\hline 'Hanahreum' & $7.55 \pm 0.10^{b}$ & $82.62 \pm 0.46^{\mathrm{a}}$ & $0.60 \pm 0.07^{\mathrm{c}}$ & $13.61 \pm 0.72^{b}$ \\
\hline 'Jasmin 85 ' & $6.91 \pm 0.29^{\mathrm{c}}$ & $82.44 \pm 0.16^{\mathrm{a}}$ & $1.35 \pm 0.06^{\mathrm{a}}$ & $13.04 \pm 0.38^{\mathrm{b}}$ \\
\hline 'Bukkyeong 2012-2' & $8.51 \pm 0.21^{\mathrm{a}}$ & $81.47 \pm 0.09^{b}$ & $0.36 \pm 0.06^{\mathrm{d}}$ & $12.94 \pm 0.07^{\mathrm{b}}$ \\
\hline
\end{tabular}

${ }^{1)}$ Values are mean \pm SD of triplicate determinations. Different superscripts within a column indicate significant differences ( $<<0.05$ ).

가루를 사용하였으며, 쌀 품종에 따른 아밀로오스 함량을 측 정하였다(data not shown). 아밀로오스 함량은 품종에 따라 북경 2012-2는 $34.12 \%$, 자스민 85 은 $25.76 \%$ 로, 한아름은 $22.27 \%$, 아로미는 $21.39 \%$ 로 나타났으며, 일반적으로 쌀은 아밀로오스 함량에 따라 분류를 하는데 고아밀로오스는 $25 \%$ 이상, 중간 아밀로오스는 $20-25 \%$, 저아밀로오스는 $7-20 \%$ 로 분류된다(Kim 등, 2019). 아밀로오스 함량의 측정방법에 따 른 약간의 편차를 가지며 본 연구의 결과 북경 2012-2, 자스 민 85은 고아밀로오스, 한아름 및 아로미는 중간 아밀로오스 로 분류할 수 있다.

팽화스낵 최적 제조조건을 찾고자 예비실험으로 스크류 속도를 $900,1,000,1,100,1,200,1,300 \mathrm{rpm}$ 으로 조절하고, 원 료투입 속도는 $400 \mathrm{rpm}$ 으로 고정하여 실험한 결과 스크류 속도가 증가함에 따라 직경팽화율이 증가하고, 또한 강도, 경 도 및 bulk density에서도 스크류 속도가 증가할수록 감소하 는 경향을 나타내었으며, 팽화정도가 $1,200 \mathrm{rpm}$ 에서 가장 높 게 나타나 최적 조건으로 설정하였다. 또한 최적 스크류 속도 $1,200 \mathrm{rpm}$ 으로 고정한 후, 원료투입 속도는 $300,350,400$, $450 \mathrm{rpm}$ 으로 조절하여 실험을 진행한 결과, 원료투입 속도가 증가할수록 직경팽화율은 감소하였으나 큰 차이는 나타나지 않으며, bulk density는 $350 \mathrm{rpm}$ 에서 가장 낮게 나타나 팽화 정도가 우수한 것으로 나타나, 최적조건으로 스크류 속도 $1,200 \mathrm{rpm}$, 원료투입속도 $350 \mathrm{rpm}$ 의 조건에서 팽화스낵제조 를 실시하였다.

수분함량은 6.65-8.51\%으로 나타났으며, 고아밀로오스인 북경 2012-2에서 $8.51 \%$ 로 가장 높게 나타났으며, 아로미에 서는 $6.65 \%$ 로 가장 낮게 나타났다. 색도의 경우, 명도를 나타 내는 L값은 81.47-82.62로 나타났고, 고아밀로오스인 북경 2012-2에서 81.47로 가장 낮게 나타났으며, 아로미, 한아름 및 자스민 85에서는 큰 차이가 나타나지 않았다. 적색도를 나 타내는 a값은 고아밀로오스인 북경 2012-2에서 0.36으로 가 장 낮게 나타났으며, 자스민 85에서 1.35로 가장 높게 나타났 다. 황색도를 나타내는 $\mathrm{b}$ 값은 고아밀로오스인 북경 2012-2에
서 12.94로 가장 낮게 나타났으며, 중간아밀로오스인 아로미 에서 14.77 로 가장 높게 나타났다.

\section{품종에 따른 쌀 팽화스낵의 bulk density, apparent density 및 porosity}

팽화스낵의 bulk density, apparent density 및 porosity는 압출성형물의 바삭바삭한 조직감에 영향을 미치는 인자로 압 출성형물의 품질을 결정하는데 중요한 물리적 특성으로 그 결과는 Table 2 와 같다. Bulk density는 0.13-0.19 g/ $\mathrm{cm}^{3}$ 로 나 타났으며, 아밀로오스 함량이 증가할수록 bulk density가 증 가하는 경향을 나타난다. Harper(1989)는 아밀로스와 아밀로 펙틴의 함량 비율이 압출성형 제품의 질에 영향을 준다고 하였 고, 고아밀로오스인 북경 2012-2 팽화스낵에서 $0.19 \mathrm{~g} / \mathrm{cm}^{3}$ 로 가장 높게 나타났으며, 중간아밀로오스 팽화스낵에서는 0.13$0.14 \mathrm{~g} / \mathrm{cm}^{3}$ 로 나타나 큰 차이는 나타나지 않았다. Apparent density는 0.69-0.83 g/ $\mathrm{cm}^{3}$ 로 나타났으며, 고아밀로오스인 북 경 2012-2 팽화스낵에서 $0.69 \mathrm{~g} / \mathrm{cm}^{3}$ 로 가장 낮게 나타났으며, 중간아밀로오스 팽화스낵에서 $0.77-0.83 \mathrm{~g} / \mathrm{cm}^{3}$ 로 나타나 북경 2012-2 팽화스낵보다 높게 나타났다. 아밀로오스 함량이 증 가할수록 apparent density는 감소하는 경향을 나타내었다.

Porosity는 0.72-0.84\%으로 나타났으며, 아밀로오스 함량 이 증가할수록 porosity가 감소하는 경향을 나타내었다. Porosity는 팽화정도를 나타내며, Eun 등(2014)에 따르면 아 밀로오스 함량이 증가할수록 porosity는 유의적으로 증가되 어 bulk density와는 반대의 결과를 나타낸다고 보고하여 본 연구결과와 일치하였다.

\section{품종에 따른 쌀 팽화스낵의 직경팽화율 및 specific length}

품종에 따른 쌀 팽화스낵의 직경팽화율은 Table 2 와 같이 아밀로오스 함량이 증가할수록 유의적으로 감소하는 경향을 나타내었으며, 아밀로오스 함량이 가장 낮은 아로미 팽화스 낵에서 $12.09 \%$ 로 가장 높게 측정되었다. 고아밀로오스인 옥 수수 전분의 혼합물 연구에서 압출성형기의 온도가 $130^{\circ} \mathrm{C}$ 일 
Table 2. Bulk density, apparent density, porosity, expansion ratio and specific length of extruded rice snacks based on the rice cultivar

\begin{tabular}{cccccc}
\hline Sample & $\begin{array}{c}\text { Bulk density } \\
\left(\mathrm{g} / \mathrm{cm}^{3}\right)\end{array}$ & $\begin{array}{c}\text { Apparent density } \\
\left(\mathrm{g} / \mathrm{cm}^{3}\right)\end{array}$ & Porosity & $\begin{array}{c}\text { Expansion } \\
\text { ratio }\end{array}$ & $\begin{array}{c}\text { Specific length } \\
(\mathrm{mm} / \mathrm{g})\end{array}$ \\
\hline 'Aromi' & $0.13 \pm 0.01^{\mathrm{bl})}$ & $0.81 \pm 0.02^{\mathrm{a}}$ & $0.84 \pm 0.01^{\mathrm{a}}$ & $12.09 \pm 0.38^{\mathrm{a}}$ & $78.59 \pm 4.31^{\mathrm{c}}$ \\
'Hanahreum' & $0.14 \pm 0.01^{\mathrm{b}}$ & $0.77 \pm 0.02^{\mathrm{b}}$ & $0.81 \pm 0.01^{\mathrm{a}}$ & $11.12 \pm 0.54^{\mathrm{c}}$ & $96.98 \pm 6.55^{\mathrm{a}}$ \\
'Jasmin 85' & $0.14 \pm 0.01^{\mathrm{b}}$ & $0.83 \pm 0.01^{\mathrm{a}}$ & $0.84 \pm 0.01^{\mathrm{a}}$ & $11.78 \pm 0.49^{\mathrm{ab}}$ & $75.79 \pm 5.65^{\mathrm{c}}$ \\
'Bukkyeong 2012-2' & $0.19 \pm 0.02^{\mathrm{a}}$ & $0.69 \pm 0.02^{\mathrm{c}}$ & $0.72 \pm 0.03^{\mathrm{b}}$ & $11.67 \pm 0.46^{\mathrm{b}}$ & $82.99 \pm 5.00^{\mathrm{b}}$ \\
\hline
\end{tabular}

${ }^{1)}$ Values are mean \pm SD of triplicate determinations. Different superscripts within a column indicate significant differences $(p<0.05$ ).

때는 아밀로오스 함량이 증가할수록 팽화율이 감소하였으며, 아밀로펙틴은 압출성형물의 light, elastic, smooth를 증가시 키고 표면을 견고히 하며, 세포벽에 균일한 조직감을 부여하 는 반면 아밀로오스는 압출성형물을 단단하게 하고 팽화율 을 감소시킨다고 보고하였다(Mercier와 Felillet, 1975). 아밀 로오스 함량 및 배럴 온도에 따른 팽화스낵 연구에서는 온도 가 높아질수록 호화 정도가 높아져 분자가 더 잘 늘어날 수 있기 때문에 저아밀로오스가 팽화가 잘 된다고 보고하였다 (Guha와 Ali, 2006). Specific length는 78.59-82.99 mm/g으로 나타났으며, 아밀로오스 함량이 증가할수록 specific length는 유의적으로 증가하는 경향을 보였으며, 고아밀로오스인 북경 2012-2 팽화스낵에서 $82.99 \mathrm{~mm} / \mathrm{g}$ 으로 가장 높게 나타났다.

\section{품종에 따른 쌀 팽화스낵의 강도 및 경도}

쌀 품종별 강도 및 경도 결과는 Table 3 과 같다. 강도의 경우, 아로미, 한아름 및 자스민 85 순으로 아밀로오스 함량 이 낮을수록 낮게 나타났으며, 경도의 경우, 아로미에서 가장 낮은 경도 값을 가져 아밀로오스 함량이 낮을수록 낮게 나타 나 강도와 유사한 경향을 나타내었다. 고아밀로오스인 북경 2012-2 팽화스낵에서 강도 및 경도는 각각 $2,849.53 \mathrm{~g} / \mathrm{cm}^{2}$, $11,822.57 \mathrm{~g} / \mathrm{cm}^{2}$ 로 나타나 가장 높게 측정되었으며, 아밀로 오스 함량이 증가할수록 강도 및 경도는 증가하는 경향을 나 타내었다. 이는 Bhattacharya 등(1986)의 연구에서는 압출팽 화물에서 팽화율이 클수록 텍스쳐는 작아진다고 보고하였는
데, 아밀로오스는 압출성형물을 단단하게 하고, 팽화율을 감 소시킨다고 보고되어 아밀로오스 함량이 높은 압출성형물일 수록 텍스쳐가 높을 것으로 판단된다. 또한, Shin 등(2003)에 따르면 팽화 후에도 압출성형물 내에 수분함량이 많을수록 형성된 기공이 수축하여 곡류의 조직이 단단해진다고 보고하 여, 팽화스낵의 수분함량이 가장 높게 나타난 북경 2012-2에 서 강도 및 경도가 높게 나타난 것으로 사료된다.

\section{품종에 따른 쌀 팽화스낵의 수분용해지수 및 수분흡수지수}

수분용해지수(WSI)는 아밀로오스 함량이 증가할수록 감 소하는 경향을 나타내었다. 수분용해지수는 전분과 단백질의 수화를 나타내는 지표로서(Mason과 Hoseney, 1986), 호화도 와 팽화율에 영향을 받으며, 스낵 제품으로서 이들의 수치는 높을수록 좋은 품질로 인정된다. 아밀로오스 함량을 달리하 여 제조한 압출성형 스낵의 수분용해지수는 아밀로오스 함량 이 증가할수록 감소하였다. 이는 대부분 불용성 물질로 구성 되어 있는 아밀로오스로 인해 상대적으로 감소한 수용성 성 분의 양에 비례하여 감소한 것으로 보고된다(Jeong 등, 2002). 수분흡수지수(WAI)는 아밀로오스 함량이 증가할수록 증가하는 경향을 나타내었다. 수분흡수력은 중간아밀로오스 팽화스낵에서는 아로미 팽화스낵에서 7.08, 북경 2012-2 팽 화스낵에서 10.06으로 아밀로오스 함량이 낮을수록 낮게 나 타났다. Jin 등(1995)의 보고에 의하면 팽화가 많이 될수록 수분흡수지수는 낮고, 수분용해지수는 높다고 하였는데, 본

Table 3. Strength, hardness, water soluble index and water absorption index of extruded rice snacks based on the rice cultivar

\begin{tabular}{ccccc}
\hline Sample & Strength $\left(\mathrm{g} / \mathrm{cm}^{2}\right)$ & Hardness $\left(\mathrm{g} / \mathrm{cm}^{2}\right)$ & $\begin{array}{c}\text { Water soluble index } \\
\text { (WSI, \%) }\end{array}$ & $\begin{array}{c}\text { Water absorption index } \\
\text { (WAI) }\end{array}$ \\
\hline 'Aromi' & $1,814.0 \pm 121.5^{\mathrm{d} 1)}$ & $7,364.1 \pm 1443.8^{\mathrm{c}}$ & $10.28 \pm 0.53^{\mathrm{b}}$ & $7.08 \pm 0.60^{\mathrm{b}}$ \\
'Hanahreum' & $2,100.2 \pm 197.3^{\mathrm{c}}$ & $10,195.0 \pm 1114.5^{\mathrm{b}}$ & $10.00 \pm 0.83^{\mathrm{b}}$ & $9.74 \pm 0.93^{\mathrm{a}}$ \\
'Jasmin 85' & $2,435.8 \pm 139.6^{\mathrm{b}}$ & $9,733.9 \pm 996.0^{\mathrm{b}}$ & $19.91 \pm 0.72^{\mathrm{a}}$ & $9.15 \pm 0.81^{\mathrm{a}}$ \\
'Bukkyeong 2012-2' & $2,849.5 \pm 271.2^{\mathrm{a}}$ & $11,822.6 \pm 1331.8^{\mathrm{a}}$ & $6.80 \pm 0.85^{\mathrm{c}}$ & $10.06 \pm 0.52^{\mathrm{a}}$ \\
\hline
\end{tabular}

${ }^{1)}$ Values are mean \pm SD of triplicate determinations. Different superscripts within a column indicate significant differences $(p<0.05)$. 
실험과 같은 경향을 나타냈다.

\section{품종에 따른 쌀 팽화스낵의 시차열주사분석(DSC)}

쌀품종별에 따른 팽화스낵의 DSC 결과는 Table 4와 같다. 흡열반응곡선은 $29.89-110.05^{\circ} \mathrm{C}$ 의 온도범위로 품종에 따른 최대 호화온도는 아로미, 한아름, 자스민 85, 북경 2012-2 순 으로 각각 $77.55^{\circ} \mathrm{C}, 75.77^{\circ} \mathrm{C}, 74.36^{\circ} \mathrm{C}, 81.49^{\circ} \mathrm{C}$ 로 고아밀로오 스인 북경 2012-2에서 가장 높게 나타났으며, 또한 엔탈피도 $58.91-108.60 \mathrm{~J} / \mathrm{g}$ 범위로 북경 2012-2에서 가장 높게 나타나, 최대호화온도 결과와 유사한 경향을 나타내었다. 건조양파착 즙박 스낵의 흡열반응곡선은 $59.18-75.77^{\circ} \mathrm{C}$, 건조양파스낵의 흡열반응곡선은 $58.92-73.05^{\circ} \mathrm{C}$ 로 나타났으며, 최대호화온도 는 $65.72-70.39^{\circ} \mathrm{C}$ 로 나타나 본 연구결과보다 다소 낮게 측정 되었다(Kee 등, 2001). 또한, Yoon과 Lee(1998)에 따르면 옥 수수 전분의 상전이 온도범위는 $67.15-80.94^{\circ} \mathrm{C}$ 이었고 최대 peak는 $71.15^{\circ} \mathrm{C}$ 로 보고하여 본 연구결과보다 다소 낮게 측정 되었다.

\section{옥수수가루 배합에 따른 쌀 팽화스낵의 수분함량 및 색도}

품종에 따른 쌀 팽화스낵의 품질특성 비교 시 아로미를 이 용한 팽화스낵에서 품질특성이 가장 우수하여 아로미와 옥수 수가루 배합비율 $(0,30,50,70$ 및 $100 \%, \mathrm{w} / \mathrm{w})$ 을 달리하여
쌀 팽화스낵을 제조하였으며, 수분함량 및 색도는 Table 5에 나타내었다. 수분함량은 4.87-6.05\%으로 나타났으며, 쌀가루 함량이 증가함에 따라서는 유의적인 차이는 없었지만, 대조 구(옥수수 $100 \%$ )에 대비하여 수분함량이 유의적으로 낮게 나타났다.

색도의 경우, $\mathrm{L}$ 값, $\mathrm{a}$ 값 및 $\mathrm{b}$ 값은 각각 74.79-77.22, 1.60$3.59,16.46-26.37$ 로 나타났으며, $\mathrm{L}$ 값은 쌀가루 첨가량이 증 가할수록 유의적으로 증가하였으나, 반대로 $\mathrm{a}$ 값 및 $\mathrm{b}$ 값은 유 의적으로 감소하는 경향을 나타내었다. 이는 쌀가루와 옥수 수가루의 비율을 달리하여 제조한 생선스낵의 품질특성을 비 교한 $\operatorname{Sim}$ 등(2001)의 연구에서 쌀가루 함량이 증가할수록 L 값이 증가하였으며, 반대로 옥수수가루 함량이 증가할수록 b 값이 증가하는 결과와 같은 경향을 나타내었다.

\section{옥수수가루 배합에 따른 쌀 팽화스낵의 bulk density, apparent density 및 porosity}

옥수수가루를 첨가한 팽화스낵의 bulk density, apparent density 및 porosity는 Table 6에 나타내었다. Bulk density는 0.10-0.14 g/cm로로 나타나 쌀가루 첨가량에 따른 큰 차이를 나타내지 않았으나, 쌀가루 $70 \%$ 로 제조한 팽화스낵에서 가 장 낮게 나타났다. Apparent density는 0.69-0.79 g/ $\mathrm{cm}^{3}$ 로 나 타났으며, 쌀가루 첨가량이 증가할수록 apparent density가

Table 4. Differential scanning calorimeter (DSC) of extruded rice snacks based on the rice cultivar

\begin{tabular}{cccccc}
\hline & & Gelatinization temperature & & Enthalpy \\
\cline { 2 - 5 } Sample & To & Tp & Tc & \multicolumn{1}{c}{$\Delta \mathrm{H}^{1)}$} \\
\hline 'Aromi' & 29.89 & 77.55 & 106.66 & 82.79 \\
'Hanahreum' & 30.19 & 75.77 & 102.21 & 81.64 \\
'Jasmin 85' & 31.42 & 74.36 & 100.68 & 78.91 \\
'Bukkyeong 2012-2' & 30.50 & 81.49 & 110.95 & 108.60 \\
\hline
\end{tabular}

${ }^{1)} \mathrm{To}, \mathrm{Tp}$, Tc mean, onset, peak, and conclustion transtition tempaerature, respectively.

Table 5. Moisture content and color of extruded rice snacks based on the com flour ratio

\begin{tabular}{ccccc}
\hline \multirow{2}{*}{$\begin{array}{c}\text { Ratio }(\%) \text { of } \\
\text { corn flour and rice flour }\end{array}$} & $\begin{array}{c}\text { Moisture } \\
\text { content }(\%)\end{array}$ & Lightness $\left(\mathrm{L}^{*}\right)$ & Color value \\
\cline { 3 - 5 } $100: 0$ & $6.05 \pm 0.39^{\mathrm{al})}$ & $74.79 \pm 0.13^{\mathrm{c}}$ & $1.64 \pm 0.03^{\mathrm{c}}$ & $26.37 \pm 0.16^{\mathrm{a}}$ \\
$70: 30$ & $5.12 \pm 0.15^{\mathrm{b}}$ & $75.33 \pm 0.23^{\mathrm{c}}$ & $3.47 \pm 0.06^{\mathrm{ab}}$ & $24.08 \pm 0.55^{\mathrm{b}}$ \\
$50: 50$ & $4.87 \pm 0.14^{\mathrm{b}}$ & $76.06 \pm 0.47^{\mathrm{b}}$ & $3.59 \pm 0.14^{\mathrm{a}}$ & $22.64 \pm 0.22^{\mathrm{c}}$ \\
$30: 70$ & $5.05 \pm 0.18^{\mathrm{b}}$ & $76.40 \pm 0.43^{\mathrm{b}}$ & $3.29 \pm 0.16^{\mathrm{b}}$ & $21.91 \pm 0.19^{\mathrm{d}}$ \\
$0: 100$ & $5.06 \pm 0.39^{\mathrm{b}}$ & $77.22 \pm 0.40^{\mathrm{a}}$ & $1.60 \pm 0.04^{\mathrm{c}}$ & $16.46 \pm 0.02^{\mathrm{e}}$ \\
\hline
\end{tabular}

\footnotetext{
${ }^{1)}$ Values are mean \pm SD of triplicate determinations. Different superscripts within a column indicate significant differences $(\mathrm{p}<0.05$ ).
} 
Table 6. Bulk density, apparent density, porosity, expansion ratio and specific length of extruded rice snacks based on the com flour ratio

\begin{tabular}{|c|c|c|c|c|c|}
\hline $\begin{array}{l}\text { Ratio }(\%) \text { of } \\
\text { corn flour and rice } \\
\text { flour }\end{array}$ & $\begin{array}{l}\text { Bulk density } \\
\qquad\left(\mathrm{g} / \mathrm{cm}^{3}\right)\end{array}$ & $\begin{array}{l}\text { Apparent density } \\
\qquad\left(\mathrm{g} / \mathrm{cm}^{3}\right)\end{array}$ & Porosity & $\begin{array}{l}\text { Expansion } \\
\text { ratio }\end{array}$ & $\begin{array}{l}\text { Specific length } \\
(\mathrm{mm} / \mathrm{g})\end{array}$ \\
\hline $100: 0$ & $0.10 \pm 0.01^{\mathrm{d} 1)}$ & $0.69 \pm 0.02^{b}$ & $0.86 \pm 0.01^{\mathrm{ab}}$ & $10.81 \pm 0.85^{\mathrm{a}}$ & $110.05 \pm 12.87^{\mathrm{c}}$ \\
\hline $70: 30$ & $0.12 \pm 0.01^{\mathrm{b}}$ & $0.69 \pm 0.03^{\mathrm{b}}$ & $0.83 \pm 0.01^{\mathrm{c}}$ & $10.70 \pm 0.42^{\mathrm{a}}$ & $113.53 \pm 10.28^{\mathrm{c}}$ \\
\hline $50: 50$ & $0.11 \pm 0.01^{\mathrm{c}}$ & $0.71 \pm 0.01^{\mathrm{b}}$ & $0.85 \pm 0.01^{b}$ & $10.87 \pm 0.54^{\mathrm{a}}$ & $122.94 \pm 6.91^{\mathrm{b}}$ \\
\hline $30: 70$ & $0.10 \pm 0.01^{\mathrm{d}}$ & $0.73 \pm 0.06^{\mathrm{ab}}$ & $0.87 \pm 0.01^{\mathrm{a}}$ & $10.97 \pm 0.37^{\mathrm{a}}$ & $138.94 \pm 6.33^{\mathrm{a}}$ \\
\hline $0: 100$ & $0.14 \pm 0.01^{\mathrm{a}}$ & $0.79 \pm 0.03^{\mathrm{a}}$ & $0.82 \pm 0.01^{\mathrm{c}}$ & $11.19 \pm 0.56^{\mathrm{a}}$ & $96.81 \pm 3.87^{\mathrm{d}}$ \\
\hline
\end{tabular}

${ }^{1)}$ Values are mean \pm SD of triplicate determinations. Different superscripts within a column indicate significant differences ( $<<0.05$ ).

유의적으로 증가하는 경향을 나타내었다. 팽화정도를 나타내 는 porosity는 대조구에서는 $0.86 \%$ 로 나타났으며, 쌀가루 $70 \%$ 로 제조한 팽화스낵에서 $0.87 \%$ 로 가장 높게 나타났다. 압출성형 과정에서 생성되는 porosity는 팽화정도를 나타내는 것으로, bulk density와는 음의 상관관계를 가진다고 보고하여 본 연구결과와 같은 경향을 나타내었다(Thymi 등, 2005; Yanniotis 등, 2007). Chinnaswamy 등(1988)에 따르면 압출 성형 시 최적공정조건은 전분의 형태에 따라 달라진다고 보 고하였으며, 압출성형하는 동안에 밀과 옥수수전분의 호화도 가 증가함에 따라 팽화율은 증가하고, 밀도는 감소한다고 보 고하였다(Case 등, 1992).

\section{옥수수가루 배합에 따른 쌀 팽화스낵의 직경팽화율 및 specific length}

쌀가루 및 옥수수가루를 첨가하여 제조한 팽화스낵의 직 경팽화율 및 specific length는 Table 6에 나타내었다. 직경팽 화율은 10.81-11.19\%로 나타났으며, 옥수수가루로 제조한 팽화스낵은 $10.81 \%$ 로 나타났다. 쌀가루를 첨가한 팽화스낵 은 10.70-11.19\%로 나타났으며, 쌀가루 첨가량이 증가할수 록 직경팽화율이 증가하는 경향을 나타내었다. 일반적으로 팽화스낵의 밀도가 높으면 팽화가 덜 일어나는데(Yagc와
Gogus, 2008), 본 연구에서는 옥수수가루와 쌀가루의 혼합비 에 따른 큰 차이는 나타나지 않았다. Specific length는 96.81-138.94 mm/g으로 나타났으며, 쌀가루 첨가량이 증가 할수록 specific length가 유의적으로 증가하는 경향을 보였 으나, 쌀가루 $100 \%$ 로 제조한 팽화스낵에서는 $96.81 \mathrm{~mm} / \mathrm{g}$ 으 로 낮아졌다. 따라서 본 연구에서는 옥수수가루와 쌀가루의 30:70 비율에서 bulk density가 가장 낮고, specific length 및 porosity가 가장 높게 나타나 팽화스낵 제조시 적합한 품질특 성을 가질 것이라고 판단된다.

\section{옥수수가루 배합에 따른 쌀 팽화스낵의 강도 및 경도}

쌀가루 대체비율에 따른 팽화스낵의 강도 및 경도는 Table 7와 같이 각각 $1,573.50-2,022.00 \mathrm{~g} / \mathrm{cm}^{2}, 4,348.05-7,006.70$ $\mathrm{g} / \mathrm{cm}^{2}$ 로 나타났다. 강도 및 경도의 대조구는 각각 $2,022.00$ $\mathrm{g} / \mathrm{cm}^{2}$ 및 $7,006.70 \mathrm{~g} / \mathrm{cm}^{2}$ 로 가장 높게 나타났다. 쌀가루 첨가 량이 증가할수록 강도 및 경도는 유의적으로 감소하는 경향 을 보였으며 쌀가루 $70 \%$ 로 제조한 팽화스낵에서는 강도 및 경도가 각각 $1,573.50 \mathrm{~g} / \mathrm{cm}^{2}, 4,348.05 \mathrm{~g} / \mathrm{cm}^{2}$ 로 가장 낮게 나 타났다. Bhattacharya 등(1986)의 연구에서는 압출팽화물에 서 팽화율이 클수록 텍스쳐는 작아진다고 보고하였으며, 직 경팽화율 및 porosity가 높은 쌀가루 $70 \%$ 팽화스낵에서는 강

Table 7. Strength, hardness, water soluble index and water absorption index of extruded rice snacks based on the corn flour ratio

\begin{tabular}{ccccc}
\hline $\begin{array}{c}\text { Ratio (\%) of } \\
\text { corn flour and rice flour }\end{array}$ & $\begin{array}{c}\text { Strength } \\
\left(\mathrm{g} / \mathrm{cm}^{2}\right)\end{array}$ & $\begin{array}{c}\text { Hardness } \\
\left(\mathrm{g} / \mathrm{cm}^{2}\right)\end{array}$ & $\begin{array}{c}\text { Water soluble index } \\
(\text { WSI, \%) }\end{array}$ & $\begin{array}{c}\text { Water absorption index } \\
\text { (WAI) }\end{array}$ \\
\hline $100: 0$ & $2,022.0 \pm 96.4^{\mathrm{al})}$ & $7,006.7 \pm 772.4^{\mathrm{a}}$ & $14.67 \pm 1.53^{\mathrm{c}}$ & $4.49 \pm 0.34^{\mathrm{b}}$ \\
$70: 30$ & $1,776.0 \pm 41.0^{\mathrm{b}}$ & $5,433.8 \pm 402.6^{\mathrm{c}}$ & $16.00 \pm 1.73^{\mathrm{c}}$ & $4.10 \pm 0.27^{\mathrm{b}}$ \\
$50: 50$ & $1,691.5 \pm 51.1^{\mathrm{c}}$ & $5,043.3 \pm 250.1^{\mathrm{d}}$ & $22.33 \pm 0.58^{\mathrm{b}}$ & $4.31 \pm 0.16^{\mathrm{b}}$ \\
$30: 70$ & $1,573.5 \pm 53.9^{\mathrm{d}}$ & $4,348.1 \pm 281.8^{\mathrm{e}}$ & $24.67 \pm 1.15^{\mathrm{b}}$ & $4.44 \pm 0.32^{\mathrm{b}}$ \\
$0: 100$ & $1,777.6 \pm 92.6^{\mathrm{b}}$ & $5,764.0 \pm 431.6^{\mathrm{b}}$ & $29.33 \pm 1.15^{\mathrm{a}}$ & $7.55 \pm 0.30^{\mathrm{a}}$ \\
\hline
\end{tabular}

${ }^{1)}$ Values are mean \pm SD of triplicate determinations. Different superscripts within a column indicate significant differences ( $<<0.05$ ). 
도 및 경도가 가장 낮게 측정되어 본 연구결과와 일치하였다.

\section{옥수수가루 배합에 따른 쌀 팽화스낵의 수분용해지수 및 수분흡수지수}

옥수수가루 배합에 따른 쌀 팽화스낵의 수분용해지수 및 수분흡수지수는 Table 7과 같다. 수분용해지수(WSI)는 쌀가 루 첨가량이 증가할수록 수분용해지수는 유의적으로 증가하 는 경향을 나타내었다. 직경팽화율이 가장 높은 쌀가루 $100 \%$ 를 첨가한 팽화스낵에서 수분용해지수가 가장 높게 나 타났다. 수분흡수지수(WAI)는 쌀가루 대체비율 $30 \%, 50 \%$, $70 \%$ 에서 각각 $4.10,4.31,4.44$ 로 나타나 대조구에 비해 낮게 측정되었으나, $100 \%$ 쌀가루로 제조한 팽화스낵에서는 7.55 로 가장 높게 측정되었다. 일반적으로 수분흡수지수는 호화 전분의 흡습성으로 인하여 호화전분에 비례하는 밀접한 관계 를 가지며(Mariotti 등, 2006), 수분용해지수와 수분흡수지수 는 혼합물의 종류와 비율에 따라 차이가 나타난다고 보고하 여(Wen 등, 1990) 쌀과 옥수수 전분 구조의 차이가 수분용해 지수 및 수분흡수지수에 영향을 미친 것으로 판단된다.

\section{요 약}

본 연구는 쌀의 이용성 증대를 위하여 쌀 품종 및 옥수수 가루 배합비율을 달리하여 압출성형기를 이용한 팽화스낵의 품질특성을 살펴보았다. 쌀의 품종별로 팽화스낵의 물리적 특성을 비교한 결과, 수분함량 및 bulk density는 아밀로스 함 량이 낮을수록 감소하였으며, 이와 반대로 직경팽화율 및 porosity는 아밀로스 함량이 증가할수록 감소하는 경향을 나 타내었다. 강도 및 경도는 아밀로스 함량이 증가할수록 유의 적으로 증가하는 경향을 나타내었으며, 아로미 팽화스낵에서 가장 낮게 측정되었다. 수분용해지수 및 수분흡수지수는 아 밀로스 함량이 증가할수록 각각 감소 및 증가하는 경향을 나 타내었다. 시차주사열분석은 아밀로스 함량이 높을수록 호화 개시온도, 호화피크온도, 호화종료온도 및 엔탈피가 높게 나 타났다. 쌀가루와 옥수수 배합비를 달리한 팽화스낵의 수분 함량은 시료간의 유의적인 차이가 나타나지 않았으며, 색도 는 쌀가루 첨가량이 증가할수록 $\mathrm{L}$ 값이 유의적으로 증가하였 으며, 반대로 $\mathrm{b}$ 값은 유의적으로 감소하는 경향을 나타내었 다. 밀도는 쌀가루 첨가량이 증가할수록 밀도가 증가하는 경 향을 나타내었으나, 큰 차이는 나타나지 않았다. 직경팽화율, specific length 및 porosity는 쌀가루 첨가량이 증가할수록 증 가하는 경향을 나타내었으며, 쌀가루 첨가 $70 \%$ 로 제조한 팽 화스낵에서 가장 높게 나타났다. 강도 및 경도는 쌀가루 첨가 량이 증가할수록 감소하는 경향을 보였으며, 쌀가루 첨가 $70 \%$ 로 제조한 팽화 스낵에서 가장 낮게 나타났다. 수분용해
지수 및 수분흡수지수는 쌀가루 첨가량이 증가할수록 유의적 으로 증가하는 경향을 나타내었다. 따라서 쌀 품종별로는 아 로미를 이용해 제조한 팽화스낵에서 가장 우수한 품질특성을 나타내었으며, 쌀가루(아로미)와 옥수수가루의 최적 배합비 율은 쌀가루 $70 \%$, 옥수수가루 $30 \%$ 로 제조한 팽화스낵의 품 질특성이 가장 우수한 것으로 나타났다.

\section{감사의 글}

본 연구는 농촌진흥청 어젠다사업(과제번호: PJ01164703) 의 연구비 지원에 의해 연구되었으며, 이에 감사드립니다.

\section{Conflict of interests}

The authors declare no potential conflict of interest.

\section{ORCID}

Jung-Min Kim https://orcid.org/0000-0003-3193-3594 Kwang-Sup Youn https://orcid.org/0000-0001-7451-0554

\section{References}

Anderson RA. Gelatinization of corn grits by roll- and extrusion-cooking. Cereal Sci Today, 14, 4-12 (1969)

Bhatnagar S, Hanna MA. Physical, mechanical, and thermal properties of starch-based plastic foams. Trans ASAE, 38, 567-571 (1995)

Bhattacharya M, Hanna MA, Kaufman RE. Textural properties of extruded plant protein blends. J Food Sci, 51, 988-993 (1986)

Bouzaza D, Arhaliass A, Bouvier JM. Die design and dough expansion in low moisture extrusion-cooking process. J Food Eng, 29, 139-152 (1996)

Case SE, Hamann DD, Schwartz SJ. Effect of starch gelatinization on physical properties of extrused wheatand corn-based products. Cereal Chem, 69, 401-404 (1992)

Chinnaswamy R, Hanna MA. Relaionship between amylose content and extrusion-expansion properties of corn starches. Cereal Chem, 65, 138-143 (1988)

Cho SY, Jeong DH, Ryu GH. Effect of extrusion process variable on physicochemical properties of extruded rice snack with mealworm. Korean J Food Sci Technol, 49, 444-452 (2017) 
Choi HC. Current status and perspectives in varietal improvement of rice cultivars for high-quality and valueadded products. Korean J Crop Sci, 47, 15-32(2002)

Eun JB, Hsieh FH, Choi OJ. Physicochemical properties of rice-based expanded snacks according to extrusion conditions. J Korean Soc Food Sci Nutr, 43, 1407-1414 (2014)

Gu BJ, Norajit K, Ryu GH. Physicochemical properties of extruded defatted hemp seed and its energy bar manufacturing. Food Eng Prog, 14, 127-134 (2010)

Guha M, Ali SZ. Extrusion cooking of rice: effect of amylose content and barrel temperature on product profile. J Food process preserv, 30, 706-716 (2006)

Han HM, Cho JH, Koh BK. Effect of grinding method on flour quality in different rice cultivars. J Korean Soc Food Sci Nutr, 41, 1596-1602 (2012)

Haper JM. Food extruders and their application. In: Extrusion Cooking, Mercier C, Linko P, Harper JM (Editors), AACC Inc, St Paul, MN, USA, p 91-155 (1989)

Jeong HS, Min YK, Toledo RT. Effects of low temperature extrusion method on the physical properties and cell structure of pregelatinized rice flour extrudate. Food Eng Prog, 6, 145-151 (2002)

Jin Z, Hsieh F, Huff HE. Effects of soy fiber, salt, sugar and screw speed on physical properties and microstructure of corn meal extrudate. J Cereal Sci, 22, 185-194 (1995)

Kang SH, Ryu GH. Improvement in the Yukwa manufacturing by extrusion process with $\mathrm{CO}_{2}$ gas injection. Food Sci Biotechnol, 10, 1-6 (2001)

Kee HJ, Ryu GH, Park YK. Physical properties of extruded snack made of dried onion and onion pomace. J Korean Soc Food Sci Nutr, 30, 64-69 (2001)

Kim JM, Gu YR, Park BY, Hong JH, Youn KS. Variation in the quality characteristics of different rice bran cultivar extracts upon hexane or supercritical fluid extraction. Korean J Food Preserv, 26, 673-680 (2019)

Le Reverend BJD, Edelson LR, Loret C. Anatomical, functional, physiological and behavioral aspects of the development of mastication in early childhood. Brit $\mathbf{J}$ Nutr, 111, 403-414 (2014)

Lee KH, Park JY, Lee SK, Lee YY, Lee BW, Park HY, Choi HS, Cho DH, Han SI, Oh SK. Quality characteristics of puffed snacks made from high-amylose rice varieties containing resistance starch. Korean J Crop Sci, 62, 285-292 (2017)

Mariotti M, Alamprese C, Pagani MA, Lucisano M. Effect of puffing on ultrastructure and physical characteristics of cereal grains and flours. J Cereal Sci, 43, 47-56 (2006)

Mason WR, Hoseney RC. Factors affecting the viscosity of extrusion-cooked wheat starch. Cereal Chem, 63, 436441 (1986)

Mercier C, Feillet P. Modification of carbohydrate components by extrusion-cooking of creal products. Cereal Chem, 52, 283-297 (1975)

Milner JA. Functional foods and health promotion. J Nutr, 129, 1395-1397 (1999)

Phillips RD, Chinnan MS, Granch AL, Miller J, Mcwatters $\mathrm{KH}$. Effects of pretreatment on functional and nutritional properties of cowpea meal. J Food Sci, 53, 805-809 (1988)

Pyler EJ. Physical and chemical test method. In: Baking Science and Technology, Sosland Publishing company, Kanas City, MO, USA, p 891-895 (1979)

Shin HH, Lee SH, Park BS, Rhim TS, Hwang JK. Solubilization of whole grains by extrusion and enzyme treatment. Korean J Food Sci Technol, 35, 849-855 (2003)

Sim YJ, Jung BM, Rhee KC. Quality characteristics of extruded formulated products prepared from blends of rice flour, corn flour and fish muscle by single-screw extrusion. Korean J Food Sci Technol, 33, 45-49 (2001)

Song JC, Park HJ. New Food Processing. Ulimmoonhwasa, Seoul, Korea, p 470-471 (1997)

Statistics Korea. Grain Consumption Survey-Statistical Information Report. Daejeon, Korea, http://kostat.go.kr/portal/ korea/kor_nw/1/1/index.board?bmode=read\&aSeq=3729 58. (accessed January 2018)

Suknark K, Phillips RD, Chinnan MS. Physical properties of directly expanded extrudates formulated from partially defatted peanut flour and different types of starch. Food Res Int, 30, 575-583 (1997)

Thymi S, Krokida MK, Pappa A, Maroulis ZB. Structural properties of extruded corn starch. J Food Eng, 68, 519-526 (2005)

Wen L, Rodis P, Wasserman BP. Starch fragmentation and protein insolubilization during twin-screw extrusion of 
corn meal. Cereal Chem, 67, 268-275 (1990)

Wu XB, Kim EK, Choi KY, Kim HY. Antioxidative and physical characteristics of rice germ added sweet pumpkin rice snack for infants. J Korean Soc Food Cult, 33, 62-69 (2018)

Yagci S, Gogus F. Response surface methodology for evaluation of physical and functional properties of extruded snack foods developed from food-by-products. J Food Eng, 86, 122-132 (2008)

Yang SH, Peng J, Lui WB, Lin J. Effect of adlay species and rice flour ratio on the physicochemical properties and texture characteristic of adlay-based extrudates. J Food Eng, 84, 489-494 (2008)

Yanniotis S, Petraki A, Soumpasi E. Effect of pectin and wheat fibers on quality attributes of extruded cornstarch. J Food Eng, 80, 594-599 (2007)

Yoon JY, Lee YE. Influence of amylose content on formation and characteristics of enzyme-resistant starch. J Food Sci Nutr, 3, 303-308 (1998) 